УДК 339.172～DOI: https://doi.org/10.30977/PРВ.2226-8820.2021.27.128

JEL Classification: Q 02

\title{
АНАЛІЗ СУЧАСНИХ АСПЕКТІВ РЕАЛІЗАЦІЇ МАРКЕТИНГОВИХ ЗАХОДІВ У БІРЖОВОМУ ПІДПРИЕМНИЦТВІ В УКРАЇНІ
}

\author{
Нестеренко В.Ю., канд. екон. наук, доцент \\ Харківський національний автомобільно-дорожній університет \\ Болотова Т.М., канд. екон. наук, доцент
}

Харківський торговельно-економічний інститут УІПА

Постановка проблеми. Біржова діяльність є надзвичайно важливою для розвитку економіки будь-якої держави. Саме вона $\epsilon$ ефективною ланкою сполучення між продавцем та покупцем товару, а також заходом засвоєння та перетворення вільних фінансових ресурсів суспільства. Отже, від загального стану розвитку біржового ринку багато в чому залежить рівень свободи конкуренції, а також прозорість обігу товарних та фінансових ресурсів в країні.

Аналіз останніх досліджень та публікацій. Проблемам управління розвитком біржового ринку в країні та підвищення ефективності функціонування окремих бірж присвячена значна кількість публікації, таких дослідників, як І.М. Вавдійчук, Ю.А. Дяченко, Т.А. Саприкіна, М.О. Солодкий, М.В. Гудзь [1-5]. Однак основну увагу в своїх роботах науковці приділяють вивченню загальних принципів організації та функціонування бірж, проблемам правового забезпечення їх діяльності та дослідженню статистичних показників розвитку біржового ринку в Україні, а також перспективам розвитку електронних біржових торгів $[5,6]$. Проблемам вирішення специфічних питань реалізації біржової діяльності, таких як побудова ефективної системи біржового маркетингу, в дослідженнях приділено недостатньо уваги.

Невирімені складові загальної проблеми. Не зважаючи на значну кількість досліджень, вимагає подальшого розгляду проблема побудови ефективної системи маркетингу на біржах України в умовах діджиталізації.

Формулювання цілей статmі. Метою статті є дослідження сучасних підходів до біржового маркетингу та формування рекомендації щодо залучення маркетингових заходів у біржовому підприємництві.

Виклад основного матеріалу дослідження. Існування біржової діяльності як специфічної форми організації торгівлі в ринкових умовах господарювання визначає головні принципи та особливості функціонування бірж в Україні. Саме розвиток біржової торгівлі створює умови для економічного розвитку національної економіки та формує передумови для іiі інтеграції у світові ринки. Отже, збільшення обсягів діяльності та підвищення ефективності функціонування бірж - це загальна мета усіх суб’єктів біржового ринку.

Загальною метою управління біржею, безумовно, є поширення обсягів збуту біржових послуг та залучення більшого кола клієнтів. Тому на шляху 
реалізації цієї мети стає важливим ефективне використання маркетингових заходів та інструментів, але з врахуванням специфічності біржової діяльності.

Залучення системи маркетингу у практику функціонування бірж на вітчизняному ринку є досить новим кроком, однак у світовій практиці біржової діяльності він вже кілька десятиріч підтверджує свою доцільність та ефективність.

Для більш чіткого розуміння досліджуваної проблеми, розглянемо саме визначення сутності маркетингу, як функції управління на біржі:

- поширеним є погляд, що розуміє маркетинг як одну 3 головних функцій діяльності біржі, метою якої $є$ організація збутової діяльності та просування біржових послуг від біржі до потенційного клієнта;

- 3 другої точки зору, маркетинг на біржі - це комплексне поняття, що стосується організації і управління всією біржею в цілому, метою якої $\epsilon$ створення потенційного попиту на біржові послуги 3 подальшим його задоволенням;

- іншим поширеним є погляд, який розуміє біржовий маркетинг як комплекс планування, організації, стимулювання реального та потенційного попиту на посередницькі операції біржі.

Отже, в межах визначених поглядів на сутність біржового маркетингу, можна виокремити наступні його види, відповідно до цільової направленості дій:

- маркетинг, який орієнтується на біржовий продукт або послугу, тобто такий, що має на меті просування самих інструментів біржової діяльності;

- маркетинг, кінцевою метою якого $є$ клієнт, інвестор, споживач біржової послуги, такий вид маркетингу полягає у вивченні самого клієнта біржі, його вподобань, схильності до ризиків, вимог до дохідності операцій i пропозиції відповідних біржових послуг та товарів;

- змішаний маркетинг - найбільш поширений в сучасних умовах вид маркетингу, який ситуаційно використовує інструменти обох попередніх підходів.

Найбільш ефективний та поширений в сучасних умовах підхід до біржового менеджменту, базується на використанні поглядів та технологій саме комплексного змішаного підходу до біржового маркетингу, який не фокусується виключно на просуванні біржових продуктів, або виключно не орієнтується на потенційного споживача біржової послуги. Такий біржовий маркетинг передбачає наступні практичні рівні керування діяльністю біржі: застосування маркетингових заходів для підвищення кількості клієнтів; формування переліку біржових послуг, який максимально відповідає поточним та потенційним потребам споживачів, емітентів, клієнтів; розробка прозорого механізму формування ціни біржового обслуговування на всі види біржових послуг відповідно до рівня ризику та витрат; впровадження заходів розвитку біржової інфраструктури та інформаційного обслуговування.

Практичної реалізації означеного підходу до біржового менеджменту можна досягти в сучасних умовах за допомогою двох принципових шляхів: 
- створення ефективних маркетингових служб в організаційній структурі управління біржею;

- розширення використання засобів електронної біржової торгівлі, як заходу, що найбільше відповідає сучасним тенденціям діджиталізації суспільних та економічних процесів [5-10].

Розглянемо кожен 3 цих шляхів більш докладно. В процесі реалізації біржового маркетингу шляхом створення нових або розвитку існуючих маркетингових служб можна сформувати наступний перелік сучасних напрямків їх роботи:

- сприяння підвищенню швидкості розповсюдження біржової інформації, як головного виду продукції біржі, відповідно до потреб існуючих та потенційних клієнтів;

- дослідження біржової кон'юнктури, з метою виявлення потенційно привабливих біржових продуктів та послуг;

- створення та пропозиція нових біржових продуктів та послуг та формування потенційного попиту на них маркетинговими інструментами;

- індивідуальна робота 3 ключовими учасниками торгів;

- проведення просвітницьких та професійних заходів серед існуючих та потенційних учасників торгів, формування відділів для відвідувачів, тощо.

Розглянемо другий сучасний шлях реалізації біржового менеджменту, а саме використання засобів електронної біржової торгівлі в розрізі побудови ефективної системи біржового маркетингу. Сучасна біржова діяльність все більше переходить до онлайн-простору, а обсяги угод електронної торгівлі стрімко зростають [5]. Ці процеси мають свій вплив і на особливості реалізації біржового маркетингу через наступні причини: завдяки поширенню електронних форм біржових торгів до біржового ринку отримує доступ більша кількість учасників, з принципово різними цілями участі в біржових торгах, вподобаннями, обсягами фінансових ресурсів, схильністю до ризику, тощо; маркетингові служби мають поширювати свою увагу на більшу кількість учасників ринку, це ускладнює їх сегментування, створює підвищене навантаження на працівників служб; маркетингові служби біржі мають значно розширювати перелік стандартних біржових продуктів та послуг відповідно до потреб середніх та малих учасників біржових торгів.

Однак, поряд зі складностями, які формує для біржового ринку процес діджиталізації, який i надалі поширюється, існують i значні переваги, які спонукають біржову галузь до стрімкого подальшого розвитку, а саме: значне розширення кола потенційних учасників біржових торгів; використання стандартних програмних продуктів в ході реалізації електронних торгів створює умови для вільної конкуренції та надає всім учасникам рівні можливості доступу до торгів; можливість цілодобового ведення торгів, що особливо важливо у практиці міжнародних бірж; можливість створення більшої кількості самих бірж без обмежень наявністю матеріальних ресурсів або географічним положенням; скорочення частини статей витрат на реалізацію біржової діяльності та організацію самих біржових торгів. 
Висновки з проведеного досліджсння. Отже, як бачимо, на сьогодні для ефективної роботи біржі вже недостатньо пропозиції клієнтам певного стандартного пакету біржових продуктів та послуг. Маркетингові служби сучасної біржі мають вести свою роботу в умовах стрімкої діджиталізації та збільшення обсягів електронних торгів, що в свою чергу, вимагає додаткових зусиль по оновленню переліку біржових продуктів 3 обов'язковою їх орієнтацією на конкретну цільову клієнтську аудиторію, яка стає все більшою за чисельністю та все більше неоднорідною за вимогами та цілями участі в біржових торгах.

\section{Перелік посилань}

1. Вавдійчук I. М. Сучасний стан та тенденції розвитку біржової торгівлі в Україні. Глобальні та начіональні проблеми економіки. 2017. № 15. URL: http://global-national.in.ua/archive/15-2017/36.pdf (дата звернення: 15.09.2021).

2. Дяченко Ю. А. Сучасний стан та особливості функціонування світового біржового ринку. Науковий вісник Міжнародного гуманітарного університету. 2017. №. 23. С. 51-54.

3. Саприкіна Т. А. Біржова торгівля як інструмент забезпечення лібералізації ринку електроенергії. Молодий вчений. 2016. № 2 (17). URL: http://molodyvcheny.in.ua/files/journal/2015/2/123.pdf (дата звернення: 03.09.2021).

4. Солодкий М. О. Проблеми та напрями розвитку біржового товарного ринку в Україні. Ефективна економіка. 2017. №10. URL: http:// www.economy.nayka.com.ua/?op=1\&z=5814 (дата звернення: 12.09.2021).

5. Гудзь М. В. Українські реалії та перспективи формування та функціонування біржової та електронної торгівлі. Ефективна економіка. 2017. № 10. URL: http://www.economy.nayka.com.ua/?op=1\&z=6093 (дата звернення: 26.09.2021).

6. Багацька К., Гейдор А. Бізнес-процеси в умовах диджиталізації економіки. Вісник КНТЕУ. 2019. № 5. С. 23-32.

7. Диба М. І., Гернего Ю. О. Диджиталізація економіки: світовий досвід та можливості розвитку в Україні. Фінанси України. 2018. № 7. С. 50-63.

8. Карчева Г. Т., Огородня Д. В., Опенько В. А. Цифрова економіка та їі вплив на розвиток національної та міжнародної економіки. Фінансовий nростір. 2017. № 3 (27). C. 13-21.

9. Ковальчук С. В., Ковінько О. М., Лісовський І. В. Роль цифрового маркетингу в активізації міжнародної бізнес-діяльності підприємств. Маркетинг і ичифрові технології. 2018. № 1. С. 55-73.

10. Семилітко Д. Диджиталізація в дії: як цифрова трансформація бізнесу впливає на успіх компанії. Аудитор України. 2019. № 5. С. 76-79.

\section{References}

1. Vavdiichuk, I. M. (2017). Current state and trends of exchange trade development in Ukraine [Suchasnyi stan ta tendentsii rozvytku birzhovoi torhivli v 
Ukraini], Hlobalni ta natsionalni problemy ekonomiky, No. 15, available at: http://global-national.in.ua/archive/15-2017/36.pdf (last accessed 15.09.2021).

2. Dyachenko, Yu. A. (2017). Current state and features of the world stock market [Suchasnyi stan ta osoblyvosti funktsionuvannia svitovoho birzhovoho rynku], Naukovyy visnyk Mizhnarodnoho humanitarnoho universytetu, No. 23, P. $51-54$.

3. Saprykina, T. A. (2016). Exchange trade as a instrument to ensure the electricity market liberalization [Birzhova torhivlia yak instrument zabezpechennia liberalizatsii rynku elektroenerhii], Molodyi vchenyi, No. 2 (17), available at: http://molodyvcheny.in.ua/files/journal/2015/2/123.pdf (last accessed 03.09.2021).

4. Solodkyi, M. O. (2017). Problems and development directions of the exchange commodity market in Ukraine [Problemy ta napriamy rozvytku birzhovoho tovarnoho rynku v Ukraini], Efektyvna ekonomika, No. 10, available at: http:// www.economy.nayka.com.ua/?op=1\&z=5814 (last accessed 12.09.2021).

5. Ghudzj M. V. (2017). Ukrainian realities and prospects for the formation and functioning of stock exchange and e-commerce [Ukrajinsjki realiji ta perspektyvy formuvannja ta funkcionuvannja birzhovoji ta elektronnoji torghivli], Efektyvna ekonomika, No.10, available at: http://www.economy.nayka.com.ua/?op=1\&z=6093 (last accessed 26.09.2021).

6. Baghacjka K., Ghejdor A. (2019). Business processes in terms of economy digitalization [Biznes-procesy $\mathrm{v}$ umovakh dydzhytalizaciji ekonomiky], Herald of Kyiv National University of Trade and Economics, No.5, P. 23-32.

7. Dyba M. I., Ghernegho Ju. O. (2018). Digitalization of economy: international expirienceand possibilities of development in Ukraine [Dydzhytalizacija ekonomiky: svitovyj dosvid ta mozhlyvosti rozvytku v Ukrajini], Finance of Ukraine, No.7, P. 50-63.

8. Karcheva Gh. T., Oghorodnja D. V., Openjko V. A. (2017). Digital economy and its influence on development of domestic and international economies [Cyfrova ekonomika ta ji ji vplyv na rozvytok nacionaljnoji ta mizhnarodnoji ekonomiky], Financial Space, No. 3 (27), P. 13-21.

9. Kovaljchuk S. V., Kovinjko O. M., Lisovsjkyj I. V. (2018). The role of digital marketing in activation of international business activities of enterprises [Rolj cyfrovogho marketynghu $\mathrm{v}$ aktyvizaciji mizhnarodnoji biznes-dijaljnosti pidpryjemstv], Marketing and Digital Technologies, No.1, P. 55-73.

10. Semylitko D. (2019). Digitization in action: how digital business transformation affects company success [Dydzhytalizacija $\mathrm{v}$ diji: jak cyfrova transformacija biznesu vplyvaje na uspikh kompaniji], Auditor of Ukraine, No.5, P. 76-79. 


\section{РЕФЕРАТИ РЕФЕРАТЫ ABSTRACTS}

\section{УДК 339.172; JEL Classification: Q 02}

Нестеренко В.Ю., Болотова Т.М. АНАЛІЗ СУЧАСНИХ АСПЕКТІВ РЕАЛІЗАЦІї МАРКЕТИНГОВИХ ЗАХОДІВ
ПІДПРИСМНИЦТВІ В УКРАЇНІ

Мета. Дослідження сучасних підходів до біржового маркетингу та формування рекомендації щодо залучення маркетингових заходів у біржовому підприємництві. Методика дослідження. В ході дослідження використовувалися методи аналізу і синтезу, метод логічного аналізу. Інформаційними ресурсами дослідження є електронні інформаційні ресурси і матеріали періодичних видань. Результати. Найбільш ефективний та поширений в сучасних умовах підхід до біржового менеджменту базується на використанні поглядів та технологій комплексного змішаного підходу до біржового маркетингу, який не фокусується виключно на просуванні біржових продуктів або виключно не орієнтується на потенційного споживача біржової послуги. Практичної реалізації означеного підходу до біржового менеджменту можна досягти в сучасних умовах за допомогою двох принципових шляхів: створення ефективних маркетингових служб в організаційній структурі управління біржею; розширення використання засобів електронної біржової торгівлі. Діджиталізація спонукає біржову галузь до стрімкого розвитку, що проявляється в значному розширенні кола потенційних учасників біржових торгів, створенні умов для вільної конкуренції та наданні всім учасникам рівних можливостей доступу до торгів, можливості цілодобового ведення торгів, що особливо важливо у практиці діяльності міжнародних бірж, можливості створення більшої кількості самих бірж без обмежень наявними матеріальними ресурсами або географічним положенням, скороченні частини статей витрат на реалізацію біржової діяльності та організацію самих біржових торгів. Наукова новизна. Сформовано рекомендації з залучення маркетингових заходів у біржовому підприємництві в умовах діджиталізації. Практична значущість. Запропоновані рекомендації можуть бути використані у біржовому підприємництві при формуванні ефективної системи маркетингу.

Ключові слова: біржове підприємництво, маркетингові заходи, біржовий маркетинг, біржовий менеджмент, діджиталізація, електронні біржові торги.

\section{УДК 339.172; JEL Classification: Q 02}

Нестеренко В.Ю., Болотова Т.Н. АНАЛИЗ СОВРЕМЕННЫХ АСПЕКТОВ РЕАЛИЗАЦИИ МАРКЕТИНГОВЫХ МЕРОПРИЯТИЙ В БИРЖЕВОМ ПРЕДПРИНИМАТЕЛЬСТВЕ В УКРАИНЕ

Цель. Исследование современных подходов биржевого маркетинга и формирование рекомендаций по внедрению маркетинговых мероприятий в биржевом предпринимательстве. Методика исследования. В ходе исследования использовались методы анализа и синтеза, метод логического анализа. Информационными ресурсами исследования являются электронные информационные ресурсы и материалы периодических изданий. Результаты. 
Наиболее эффективный и распространенный в современных условиях подход биржевого менеджмента базируется на использовании взглядов и технологий комплексного смешанного подхода биржевого маркетинга, который не фокусируется исключительно на продвижении биржевых продуктов или исключительно не ориентируется на потенциального потребителя биржевой услуги. Практической реализации указанного подхода в биржевом менеджмента можно достичь в современных условиях с помощью двух принципиальных путей: создание эффективных маркетинговых служб в организационной структуре управления биржей; расширение использования средств электронной биржевой торговли. Диджитализация побуждает биржевую отрасль к стремительному развитию, что проявляется в значительном расширении круга потенциальных участников биржевых торгов, создании условий для свободной конкуренции и предоставлении всем участникам равных возможностей доступа к торгам, возможности круглосуточного ведения торгов, что особенно важно в практике деятельности международных бирж, возможности создания большего количества самих бирж без ограничений имеющимися материальными ресурсами или географическим положением, сокращении части статей расходов на реализацию биржевой деятельности и организацию самих биржевых торгов. Научная новизна. Сформированы рекомендации по внедрению маркетинговых мероприятий в биржевом предпринимательстве в условиях диджитализации. Практическая значимость. Предложенные рекомендации могут быть использованы в биржевом предпринимательстве при формировании эффективной системы маркетинга.

Ключевые слова: биржевое предпринимательство, маркетинговые мероприятия, биржевой маркетинг, биржевой менеджмент, диджитализация, электронные биржевые торги.

\section{UDK 339.172; JEL Classification: Q 02}

Nesterenko V.Yu., Bolotova T.M. ANALYSIS OF MODERN ASPECTS OF IMPLEMENTATION OF MARKETING MEASURES IN EXCHANGE ENTREPRENEURSHIP IN UKRAINE

Purpose. Research of modern approaches to stock exchange marketing and formation of recommendations for attracting marketing measures in exchange business. Methodology of research. The study used methods of analysis and synthesis, the method of logical analysis. The information resources of the study are electronic information resources and materials of periodicals. Results. The most effective and widespread in modern conditions approach to exchange management is based on the use of views and technologies of a comprehensive mixed approach to exchange marketing, which does not focus solely on the promotion of exchange products or does not focus exclusively on potential consumers of exchange services. The practical implementation of this approach to exchange management can be achieved in modern conditions through two fundamental ways: the creation of effective marketing services in the organizational structure of exchange management; expanding the use of e-exchange trading. Digitalization encourages the exchange 
industry to rapid development, which is manifested in a significant expansion of potential participants in exchange trading, creating conditions for free competition and providing all participants with equal access to trading, opportunities for roundthe-clock trading, which is especially important in international exchanges. more exchanges themselves without restrictions on available material resources or geographical location, reduction of part of the cost items for the implementation of exchange activities and the organization of the exchange trades themselves. Originality. The recommendations on attraction of marketing actions in the exchange business in the conditions of digitalization are formed. Practical value. The proposed recommendations can be used in exchange business in the formation of an effective marketing system.

Key words: exchange entrepreneurship, marketing activities, exchange marketing, exchange management, digitalization, electronic exchange trading.

\section{Відомості про авторів / Сведения об авторах / About the Authors}

Нестеренко Валентина Юріївна - кандидат економічних наук, доцент, Харківський національний автомобільно-дорожній університет, доцент кафедри економіки i підприємництва, м. Харків, Україна; e-mail: valentinaonisiforova@gmail.com; ORCID: http://orcid.org/0000-0001-9899-8427. Моб. 099-499-14-28.

Нестеренко Валентина Юрьевна - кандидат экономических наук, доцент, Харьковский национальный автомобильно-дорожный университет, доцент кафедры экономики и предпринимательства, г. Харьков, Украина.

Nesterenko Valentyna - Candidate of Sciences (Economics), Associate Professor, Kharkov National Automobile and Highway University, Associate Professor at the Department of Economics and Entrepreneurship, Kharkiv, Ukraine.

Болотова Тетяна Миколаївна - кандидат економічних наук, доцент, Харківський торговельно-економічний інститут УІПА, доцент кафедри маркетингу та торговельного підприємництва, м. Харків, Україна; e-mail: tatabolotova1975@gmail.com; ORCID: http://orcid.org/0000-0003-1414-880X. Моб. 050-302-57-77.

Болотова Татьяна Николаевна - кандидат экономических наук, доцент, Харьковский торгово-экономический институт УИПА, доцент кафедры маркетинга и торгового предпринимательства, г. Харьков, Украина.

Bolotova Tatyana - Candidate of Sciences (Economics), Kharkov Institute of Trade and Economics UEPA, Associate Professor of the Department of Marketing and Trade Entrepreneurship, Kharkiv, Ukraine. 